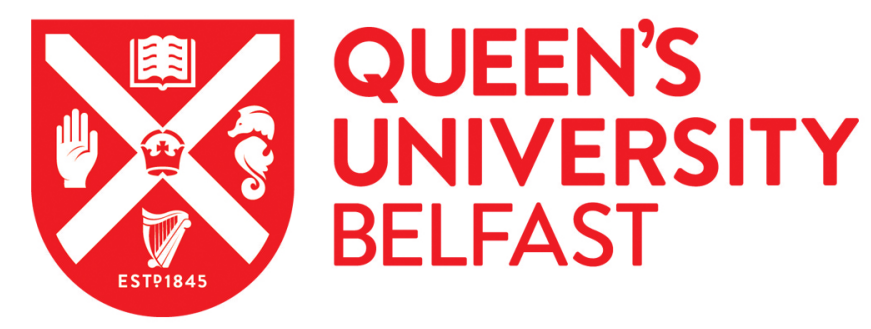

\title{
Varieties of resource nationalism in sub-Saharan Africa's energy and minerals markets
}

Andreasson, S. (2015). Varieties of resource nationalism in sub-Saharan Africa's energy and minerals markets. The Extractive Industries and Society, 2(2), 310-319. https://doi.org/10.1016/j.exis.2015.01.004

\section{Published in:}

The Extractive Industries and Society

\section{Document Version:}

Peer reviewed version

\section{Queen's University Belfast - Research Portal:}

Link to publication record in Queen's University Belfast Research Portal

\section{Publisher rights}

Copyright $\odot 2015$ Elsevier Ltd.

This manuscript version is made available under a Creative Commons Attribution-NonCommercial-NoDerivs License

(https://creativecommons.org/licenses/by-nc-nd/4.0/), which permits distribution and reproduction for non-commercial purposes, provided the author and source are cited.

\section{General rights}

Copyright for the publications made accessible via the Queen's University Belfast Research Portal is retained by the author(s) and / or other copyright owners and it is a condition of accessing these publications that users recognise and abide by the legal requirements associated with these rights.

Take down policy

The Research Portal is Queen's institutional repository that provides access to Queen's research output. Every effort has been made to ensure that content in the Research Portal does not infringe any person's rights, or applicable UK laws. If you discover content in the Research Portal that you believe breaches copyright or violates any law, please contact openaccess@qub.ac.uk. 


\title{
VARIETIES OF RESOURCE NATIONALISM IN SUB-SAHARAN AFRICA'S ENERGY AND MINERALS MARKETS*
}

\author{
Stefan Andreasson \\ Queen's University Belfast
}

\begin{abstract}
This article examines resource nationalism in sub-Saharan Africa's energy and minerals markets. It does so by exploring economic and political developments in three cases: Nigeria as an example of a petro-state established by means of expropriation in the wake of decolonisation; South Africa, a mature mining industry shaped by its settler colonial history; and Mozambique, a new and therefore highly-dependent entrant into the league of significant natural gas producers. Extractive industries have played a controversial role in sub-Saharan Africa due in particular to the prevalence of the resource curse. Nevertheless, energy exports will continue to play an important role in fuelling economic growth and, potentially, also development as new deposits of natural gas and oil are discovered across the region. Resource nationalism has, moreover, increasingly constrained operations of the traditionally dominant Western energy companies, in particular as competition from state-owned energy companies in sub-Saharan Africa and from emerging powers such as China is increasing.
\end{abstract}

Keywords: resource nationalism; energy; minerals; natural resources; Africa

* Forthcoming in The Extractive Industries and Society (2015) 


\section{Introduction: Natural resources and high politics}

The spectre of resource nationalism has haunted international resource companies since the Government of Mexico, under General and President Lázaro Cárdenas, nationalised oil reserves, previously controlled by US and Anglo-Dutch companies, on 18 March 1938. That day has been commemorated in Mexico with a national holiday. A few months later, the government created Petroléos Mexicanos (PEMEX), the world's first National Oil Company (NOC), which is today one of the world's Top 20 energy companies when measured by revenue. Across the world, political fortunes have been built on resource nationalism. Saddam Hussein engineered the nationalisation of Iraq's oil in 1972 (today Iraq has the fifth largest proven reserves in the world) and used the widespread popularity and respect garnered by these efforts to subsequently launch comprehensive social and economic reform. Russian President Vladimir Putin and Venezuela's revolutionary and President Hugo Chávez have used their respective countries' oil and gas wealth to finance domestic and regional ambitions. Oil has a long history of intertwinement with high politics, but once the waves of nationalisation swept through global resource markets. The international resource companies could 'no longer count automatically on the direct diplomatic support of their home governments as they could in the days the Big Stick or the Pith Helmet' (Moran 1973, p. 273).

Of course, resource nationalism might, as per the International Energy Forum's definition, be considered no more than a case of producer nations 'wanting to make the most of their endowment' (Stevens 2008, p. 5). In his seminal and otherwise very critical account of the resource curse, Ross $(2012$, p. 8) acknowledges that "nationalization was a giant step forward for oil-producing countries' as they gained control of their resources and came to capture a much greater degree of the profits they generated. Certainly the 'golden years' of resource nationalism, the $1950 \mathrm{~s}$ through to the $1970 \mathrm{~s}$, served to rectify the hugely disadvantageous concessions granted to International Oil Companies (IOCs) by producer nations such as Iran, Iraq, Kuwait and Saudi Arabia (Stevens 2008, p. 10).

In sub-Saharan Africa, too, nationalisation of natural resources has influenced political, economic and developmental fortunes. The countries around the Gulf of Guinea constitute the core of the region's energy industry. Writing at a time just before the onset of rapid economic growth across sub-Saharan Africa came to invoke the notion of 'Africa Rising' (e.g., Lagarde 2014), Soares de Oliveira (2007, p. 269) suggested that the global economic significance of oil production in the Gulf of Guinea was 'one of the few exceptions 
in an Africa that matters less to the world economy now than at any time since the fifteenth century'. Nigeria, with its vast reserves of oil and natural gas, has long been the region's biggest prize. The nationalisation of the Nigerian oil industry, beginning with the creation of the Nigerian National Oil Corporation in 1971 and culminating in its merger with the Ministry of Petroleum to create the Nigerian National Petroleum Corporation (NNPC) in 1979, resulted in huge revenues accruing to the federal government. Oil revenue already made up $26.3 \%$ of total government revenue in 1970 , but had risen to $82.1 \%$ only four years later. Since then, oil revenue has never made up less than $60 \%$ of government revenues and has regularly peaked well above $90 \%$, 'rendering Nigeria almost completely dependent on oil' (Frynas 2000, p. 24).

The 1970s oil boom in Nigeria also produced societal conflict over how those revenues should be shared across this heterogeneous and increasingly fractured federal state (Sala-i-Martin and Subramanian 2003). Partly due to this infusion of oil wealth, Nigeria became a paradigmatic example of the problem, initially identified by Jackson and Rosberg (1982), afflicting many African states as a result of the continent's colonial history and artificial borders - the problem of having their sovereignty recognised de jure by the international system of states, but not possessing de facto the core attributes of state sovereignty. Like Nigeria, many countries in sub-Saharan Africa are in this sense 'quasistates' in which the damaging effects of a rapid infusion of oil revenues give rise to a 'resource curse' (Ross 1999), also known as the 'paradox of plenty' (Karl 1997), that is characterised by increasing corruption and conflict alongside economic stagnation.

As Ross (2012) explains, the ill effects of this curse are particularly evident in the wake of the nationalisation of resources. Ross's contention is corroborated by Jensen and Johnston (2011), who demonstrate that governments likely to nationalise resources are also more likely to renege on contracts across all sectors of the economy, thus increasing overall levels of political risk that are detrimental to government stability and to the rule of law. In addition, Jensen and Wantchekon (2004) demonstrate a strong and negative correlation between resource abundance and levels of democracy in sub-Saharan Africa, and Joffé et al. (2009, p. 3) identify resource nationalism as 'a constant, if fluctuating, systemic risk to international private operators'. Ross's (2012, pp. 4-5) contention, that 'the events of the 1970s, especially nationalization, made the problems of the oil states a lot worse' provides a useful context in which to examine the trend towards a decreasing role of IOCs in the region's markets. 
It is therefore no surprise that oil riches have often been thought of as a curse. The Venezuelan diplomat Juan Pablo Pérez Alfonso, who took the lead in creating the Organization of the Petroleum Exporting Countries (OPEC), famously described it as the 'Devil's excrement'. There is by contrast a degree of mythical glamour surrounding the discovery of gold and diamonds. In perhaps no other country is the history of mining more closely tied to the nation's fortunes than in South Africa. Its mining industry ushered in the first and most comprehensive period of industrialisation in sub-Saharan Africa. From the Anglo-Boer wars, triggered by British and Afrikaner competition for the spoils of the massive discoveries in the latter half of the nineteenth century of diamonds in Kimberley and gold on the Witwatersrand, to the post-apartheid era of Black Economic Empowerment (BEE) policies, the South African mining industry remains a key dimension of the shifting tides of political power.

Iheduru (2002), Southall (2008) and many others have documented the startling speed with which prominent individuals in the anti-apartheid and labour union movements were transformed from comrades in struggle to what Adam et al. (1998) have memorably described as 'comrades in business'. The Randlords who built South Africa's first mining fortunes in the early twentieth century, and in particular the iconic Oppenheimer family and its vast Anglo-American and De Beers empire, towered over the development of capitalism in South Africa (Lipton 1986). South Africa's former President B. J. Vorster likened the support of the country's mining industry to 'bricks in the walls of the [apartheid] regime's continued existence' (quoted in Sharife 2014). Likewise the mining magnates of the post-apartheid era, such as Deputy President Cyril Ramaphosa, former Gauteng Premier and government minister Tokyo Sexwale and South Africa's richest man Patrice Motsepe have all benefited from close connections to, and key roles in, the ruling African National Congress (ANC). These captains of industry symbolise the intersection of political and economic power since the onset of minerals-fuelled industrialisation.

While mining as a share of South Africa's national GDP has declined from a peak of about $20 \%$ in 1970 to $5 \%$ today (IMF 2012), the industry remains a politically powerful and contentious industry. This is evidenced by the recent, and by historical comparison long and destabilising, strikes in the country's mining industry that are taking a heavy toll on its economic growth and investment prospects (England 2014a). The strike at Lonmin's platinum mines at Marikana in 2012 resulted in 44 deaths, including the shooting of 34 miners by the South African police on 16 August. While South Africa's minerals industry has 
not produced a resource curse in the classic sense of that in Nigeria, its historic importance underpins and fuels current debates about the merits of nationalisation. South Africa's intermittent violence, not to mention lengthy periods of conflict in the Niger Delta and the regional warfare involving several central African nations in the eastern Democratic Republic of Congo, are further reminders that energy and mineral riches have regularly proven to be socially combustible resources across the continent (Le Billon 2001; Ross 2006).

Given that the extractive industries have played a controversial role in the political and economic developments of resource abundant countries in sub-Saharan Africa, the article proceeds as follows. First, it is argued that energy exports will continue to play an important role in fuelling economic growth and, potentially, development as new deposits of natural gas and oil are being discovered in an increasing number of countries across the region. Because resource nationalism has played an important role in sub-Saharan Africa it has also increasingly constrained the operations of the traditionally dominant Western energy companies, in particular as competition from state-owned energy companies in the region and from emerging powers like China is increasing. Second, definitions of resource nationalism in the historical context of sub-Saharan Africa are considered. The nature and evolution, as well as potential future types of of resource nationalism among the region's energy and mineral exporters, are explored by focussing on economic and political developments in three distinct cases: Nigeria, an example of a petro-state established by means of expropriation in the wake of decolonisation; South Africa, the location of a mature mining industry in a regional environment shaped by its settler colonial history; and Mozambique, a relatively new and therefore highly dependent entrant into the league of significant energy producers. Third, to better understand what resource nationalism in sub-Saharan Africa might look like in the future, and what its impact on Western energy companies might be, the article considers how Nigeria, South Africa and Mozambique fit into Bremmer and Johnston's (2009) four-fold typology of resource nationalisms. The article concludes with some thoughts about the future relevance of resource nationalism in sub-Saharan Africa.

\section{The African resource frontier}

Resource extraction has had a major impact on modern sub-Saharan Africa and there is every reason to assume that it will continue to matter greatly for its future economic and sociopolitical developments. Collier (2010) makes the obvious but sometimes overlooked point that Western countries have industrialised on the back of resource extraction since the 
beginning of the industrial revolution, while such processes in formerly colonised regions of the world are by comparison a more recent phenomenon. As for the 'frontier' of future oil exploration, it is emerging in relatively poorer (and less democratic) countries:

Historically... rich countries have been about 70 percent more likely to produce oil than poor countries, not because they are sitting on top of more petroleum, but because they have more money to invest in locating and extracting it... [having] attracted about ten times more foreign direct investment in mining, per square kilometre, than the rest of the world... In the new millennium, this has begun to change: the petroleum frontier has moved to ever-poorer countries... From 1998 to 2006, the number of oil states rose from thirty-eight to a record fifty-seven. Almost all of the new producers were low- and middle-income countries... Thanks to booming oil prices, companies found that the risks of working in poor, remote, and often badly governed countries were increasingly outweighed by the benefits of finding new reserves... In the next few years, as many as sixteen new countries-most of them in Africa and almost all of them poor-are likely to join the list. [Ross 2012, pp. 8-10]

While proven reserves of oil and gas in Africa today constitute just about $8 \%$ of global reserves, the continent is forecast to enjoy a high rate of growth in new discoveries, especially in the frontiers of exploration in central and eastern Africa (cf. IEA 2014). From 1980 to 2012, proven oil reserves increased by almost $120 \%$, from 57 to 124 billion barrels, with at least another 100 billion barrels thought to be located off the continent's shores. Proven reserves of natural gas have increased by more than $140 \%$ during that same period, from 210 trillion cubic feet (tcf) in 1980 to 509 tcf in 2012 (KPMG Africa 2013). This growth in oil and gas reserves is roughly on par with overall global growth in reserves (BP 2013).

But discoveries in sub-Saharan Africa will likely do more than merely keep pace with the rate of growth in global discoveries. The International Energy Agency (IEA 2014, p. 2) reports that '[a]lmost $30 \%$ of global oil and gas discoveries made over the last five years have been in sub-Saharan Africa, reflecting growing global appetite for African resources'. The US Geological Survey estimates that the coastal region of East Africa holds an enormous 441 tcf of gas, which is approximately 50\% more than the reserves in Saudi Arabia (Myburgh 2012). Recent estimates of significant recoverable oil deposits in Uganda, Ghana, Kenya and 
Niger, and gas in Mozambique and Tanzania, are expanding the number of countries that have the potential to become significant energy exporters. Nigeria and Angola remain by far the region's dominant producers of oil and gas, but a more diverse map is now emerging. This proliferation of actors may produce increasingly diverse approaches to governing these industries, including different types of resource nationalism (cf. Hancock and Vivoda 2014). As additional countries become energy and minerals exporters with sizeable revenues to manage, they too must make important decisions on how to balance the interests of the state and of society with those of the international resource companies, both private and stateowned, on which governments will at least initially depend on for the effective exploitation of these resources. For a region comprising some of the world's poorest countries, the potential revenues represented by these discoveries are of great significance to the producer countries themselves, even if the region's overall exports to global markets are relatively modest.

As with the energy industry, sub-Saharan Africa's mining industry is a hugely significant industry in terms of the contribution of minerals exports to national GDP. Minerals exports contribute more to national GDP in Botswana (83.7\%), Zambia (83.6\%) and the Democratic Republic of Congo (78.3\%) than in any other country in the world. Guinea (65.2\%), Mozambique (65.2\%), Mali (54.8\%), Sierra Leone (54.3\%) and Namibia (53.4\%) are also included in the International Council of Mining \& Metals list of the world's 20 most minerals-dependent countries (ICMM 2012). However, a McKinsey (2010) study on growth opportunities by economic sector in sub-Saharan Africa notes that, in line with the resource curse thesis, while the region is rich in mineral resources, mining has failed to drive economic development in the way that it has done so in countries such as Chile and Australia. Importantly, mineral-rich countries in sub-Saharan Africa have not attracted the levels of global investment in its mining industries that its share of global resources suggests it should have.

Industry experts and organisations such as the African Development Bank, the OECD Development Centre, the United Nations Economic Commission for Africa and the United Nations Development Programme have criticised governments in sub-Saharan Africa for failing to capitalise from resource booms which began in the early 2000s and ran for about a decade (Candy 2013; Kolver 2007). Furthermore, '[sub-Saharan] Africa's pattern of mining differs from that in other regions of the world': only one of the world's five largest mining companies (Anglo American) has a major share of its production in the region (McKinsey 
2010). The relatively high degree of risk associated with doing business in sub-Saharan Africa, not only threats stemming from resource nationalism but also conflict and low levels of governance, means that companies in an industry that incurs high levels of sunken costs and that have significant operations in the region will seek to dilute that risk. One way of doing so is to diversify operations geographically, to a degree that operators in other, less risky regions may feel less need to do. There is no doubt that the prevalence and types of resource nationalism in producer countries will play a role in such decisions (Joffé et al. 2009).

The substantial revenues generated by exploiting natural resources will remain important and is probably necessary for countries in sub-Saharan Africa to finance their own development. In 2008, oil exports contributed more than one third of total GDP in several sub-Saharan African countries, including Equatorial Guinea (88.4\%), Angola (72.6\%), The Republic of Congo (71\%), Gabon (52\%), Chad (45.1\%) and Nigeria (36.9\%) (African Development Bank 2010, p. 8). While total aid to Africa quadrupled from US\$11 billion to US $\$ 44$ billion in the four decades up to 2008 , with the continent being the recipient of $36 \%$ of all global aid and more than any other region (UN 2010), the oil export revenues of Nigeria alone amounted to more than US\$94 billion in 2012 (OPEC 2013). Moreover, Nigeria's former central bank governor, Lamido Sanusi, estimated that some US\$20 billion of the country's oil revenue went missing in 2012-13 and remains unaccounted for (Financial Times 2014). Sanusi was suspended as the scandal of this missing revenue emerged. The oftentimes murky economics of the extractive industries in sub-Saharan Africa aside, and despite grave concerns about the environmental impact and therefore sustainability of a carbon-based global economy (e.g., Barry 2012), Collier (2010) argues that the era of exploration for natural resources in the region is only in its early phases.

However, it is also evident that oil and gas revenues alone cannot guarantee socioeconomic development. That is the case even where, as in this article, the emphasis is on orthodox, macro-level conceptualisations of development that do not probe micro-level aspects of development in resource abundant countries (Azapagic 2004), consider more fundamental problems with the development paradigm itself (Rist 2002), or examine how the development discourse has been applied historically to Africa (Andreasson 2005). In addition to sustained economic growth that, if properly managed, can be fuelled by resource extraction, there is a need for diversification in the economic and social structures of these resource-dependent countries. A lack of diversification is a sign of failing to become 
'developmental' in the general sense of achieving the structural transformation of economy and society that has characterised developmental trajectories elsewhere, whether in the West or in East Asia (Hillbom 2012). But in most resource-dependent sub-Saharan African countries it remains the case that no other sources of revenue will in the foreseeable future replace those generated by the extractive industries.

\section{Resource nationalism in sub-Saharan Africa}

Many people cherish a view that western oil companies are agents of imperialism, forcing weak African countries to accept dictates from London and Washington. This was once true. But when OPEC countries like Saudi Arabia and Iran started to flex their muscle in the 1970s, they wrested control over the oil industry decisively away from the Seven Sisters-the haughty ancestors of today's ExxonMobil, Chevron, BP, and Shell. Since then Africa's rulers have more or less reversed the stranglehold. The bigger African producers now typically earn 70 to 90 percent of the value of their oil for their treasuries, once development costs are paid off, leaving only a modest margin for the private oil companies. This share is the best measure of the balance of power today. [Shaxson 2007, pp. 1-2]

In a survey of resource nationalism in South Africa, Butler (2013) noted that, in its simplest form, nationalisation refers to the transfer of ownership (and/or control) of assets from the private to the public sector, and privatisation to a transfer (and/or control) of assets in the opposite direction, from public to private sectors. Stevens (2008, p. 5) emphasises two basic components of resource nationalism: 'limiting the operations of [private] companies... and asserting a greater national control over natural resource development'. The author notes furthermore that resource nationalism should not simply be associated with developing countries as countries such as Canada and Australia have been noted as 'classic examples', however benign, of resource nationalism as well (Stevens 2008, p. 6; cf. Bremmer and Johnston 2009; Kim 2007).

For governments in producer countries there are many obvious benefits of resource nationalism and of increasing the state's ownership and control over natural resources. Once the state is in (greater) control or outright ownership it can more easily direct revenues from resource extraction, of which it is now able to retain a much greater share, to national development projects. Irrespective of the ambiguous record of state-led development (Doner 
1992), this might be considered desirable in the many developing countries that are heavily dependent on their resource sectors for state revenues and economic growth. That it might be possible to facilitate resources-based development where it has previously failed, such as in an oil-dependent region like the Gulf of Guinea, is the basic assumption underpinning the notion of the 'petro-developmental state' (Ovadia, forthcoming). Nationalisation may also serve to enhance the legitimacy of post-colonial governments that are thus seen as doing something concrete to rectify exploitative relationships between their own societies and the former colonial powers in which many of the international resource companies are headquartered. If more of the huge profits created by exploiting the natural resources of developing countries can be channelled into hands of these countries' governments to then be effectively used to facilitate development, then who (besides the international energy companies and their shareholders) could possibly complain?

Of course, it is all too often the case that nationalisation does not produce such results and therefore the negative aspects of nationalisation are equally obvious. Such policies frequently become potent ingredients in the dreaded 'resource curse' brew (Karl 1997):

In its most virulently populist form, resource nationalism can pose political risks for governments that pursue it. It can deprive them of the foreign technology and expertise they need to expand, or even sustain, the output and revenue streams they need for long-term survival. So long as prices remain high, governments can extend international influence and sustain popularity at home. But if and when prices begin to fall and the cash cow begins to lose weight, resource-drunk politicians may face, or produce, serious local and regional instability [Bremmer and Johnston 2009, p. 152]

Throughout the twentieth century, cycles of nationalisation and privatisation have emerged. For instance, in Latin America, nationalisation programmes of the late nineteenth and early twentieth centuries were later succeeded by alternating waves of privatisation and nationalisation, so that by the time of the controversial neoliberal privatisation programmes of the 1990s, the region found itself in a 'fifth phase' of such cycles of shifts in ownership (Chua 1995). Energy resources such as oil, as well as major public utilities, are the most common industries targeted for nationalisation because they are the most easily accessible sources of economic rents (Butler 2013, p. 13). A study of nationalisation in the global oil industry by Guriev et al. (2011) shows that, despite the manifest inefficiency of 
nationalisation, governments are more likely to choose this option when prices, and therefore also rents, are high and where political institutions are weak, as in the majority of producer countries in sub-Saharan Africa. Stevens (2008, pp. 6-7) points to the intellectual and political climate of the post-WWII decades as the wellspring of resource nationalism: the acceptance among developed countries of market failure as a recurring phenomenon, the influence of Keynesianism and the Soviet example of rapid industrialisation, as well as the influence of 'structuralist' views of the global economy in the developing world, emphasising inevitably exploitative outcomes of their attempts to integrate into global markets. Chua (1995), on the other hand, argues that the impetus for nationalisation in developing countries is rather found in nationalist impulses in society and politics (i.e., the need for the nation or 'the people' as opposed to foreigners, whether abroad or in the shape of ethnic minorities at home) to control its resources.

Whatever the causes, there has, as noted in a recent survey by Hancock and Vivoda (2014), been a resurgence in resource nationalism. It coupled with increased competition from NOCs has created more difficult investment and operating conditions for Western energy companies, and also greater uncertainty for energy-importing countries looking to diversify and secure their energy supplies (De Graaff, 2011; Victor et al., 2012). Vivoda (2009, p. 522) argues that whereas NOCs lost some ground to IOCs during the globalisation of energy markets in the 1990s, the NOCs have now reclaimed their prominence '[i]n virtually every oil-exporting country' and Western IOCs are now 'struggling to hold on to their position in most states in which they operate'. According to Maylie (2014), many countries in sub-Saharan Africa are now seeking to enact legislation aimed at giving them more influence over their energy industries as they look to embark upon or expand oil and gas exploration and production, 'part of a tide of resource nationalism on the continent'. Such efforts are under way in South Africa, Mozambique, Kenya and Tanzania. These new laws emphasise higher taxes on the energy industries, the granting of automatic equity stakes for national oil and gas companies and setting a range of job creation and related targets for international energy companies exploiting resources. The sheer size of the energy and minerals resource base in sub-Saharan Africa, and therefore the wealth that can be generated from exploiting it, means that 'the stakes are huge', and '[m]ore than ever, African countries are under public pressure to safeguard that wealth' (Maylie 2014).

Bremmer and Johnston (2009, p. 149) consider such developments 'a catalyst for the rapid rise of oil and other commodities over the last five years' (oil peaked at US\$145 per 
barrel in July 2008). Since then, the precipitous fall in the price of oil by more than $40 \%$ from June to December 2014, driven mainly by US shale oil and gas production and reduced global demand, is a further illustration of the volatility (of revenue streams) that contributes to the resource curse. It constitutes a challenge for governments and companies alike that will put some of the aforementioned developments in doubt. However, from the longer-term perspective, revenues from energy exports will remain significant and there is no likelihood of these resources being left in the ground. In order to consider the future potential of resource nationalism, it is helpful to consider in more detail a diverse set of resource abundant countries where resource nationalism has, or might in the future, play a significant role in shaping debates and determining the control and exploitation of these resources.

\subsection{Nigeria}

In addition to an economic rationale for resource nationalism, it is clear that politics, informed by the divisive historical experience of colonialism coupled with more recent fears of neo-colonial exploitation by former colonial powers (and now also the emerging powers), play an important role in explaining why countries may push to extend control over their natural resources. While the reasons for General Obasanjo's government deciding to nationalise the substantial assets of British Petroleum in 1979 were complex (Genova 2010), they clearly included an anti-colonial dimension. In addition to immediately depriving British Petroleum of about $9 \%$ of its global supplies of crude oil, nationalisation was an attempt by the Nigerian Government to exert pressure on the British Government in the negotiations over Rhodesia's transition to majority rule and in the question of the British Government's continued support for apartheid South Africa (Frynas et al. 2000, pp. 415-16). Today, however, Nigeria's energy industry is rapidly being transformed. Post-colonial relations with the West, including the role played by the IOCs in its oil and gas sectors, will diminish in the foreseeable future.

A process of divestment by IOCs has been underway since 2009, when the UK's BG Group withdrew from a large liquefied natural gas (LNG) export development involving a partnership with Chevron, Royal Dutch Shell and the NNPC. In the following year, Shell divested itself of several oil mining licenses; the pan-African Ecobank (2013) estimates that IOCs will continue to divest themselves of significant energy assets in the country. Between 2010 and 2014, some 22 oil producing blocks are likely to have been sold. With a major presence in the country since the colonial era, Shell has incurred significant losses in its 
Nigerian operations in the last few years and its divestment amounts to several billions of US dollars. Conoco Phillips and Chevron are other US-based IOCs in the process of divesting from primarily onshore and shallow water blocks. While the Ecobank $(2013$, p. 1) assumes that these divestments will not portend 'a mass wave of IOC exits from Nigeria in the nearfuture', they do offer 'the single largest opportunity' for the NNPC and emerging power NOCs (in particular Chinese ones) to expand their upstream operations in the country's oil industry.

There are several reasons why IOCs are looking to reduce their operations in Nigeria. These include the risks to onshore operations due to the lack of security in the Niger Delta which is plagued by ongoing conflict over control of oil assets and revenue (Ikelegbe 2005); a desire by IOCs to increase their focus on off-shore (in particular deep water) oil and gas exploration and extraction which is somewhat shielded from conflict and sabotage, and where their operational and technological expertise vis-à-vis the NOCs is particularly significant; increasing competition by NOCs for all energy assets in the country; and what the Ecobank (2013, p. 1) terms 'regulatory uncertainty fuelled by Nigeria's delayed oil law, the Petroleum Industry Bill'. As oil production has recently declined in Nigeria and its crucial US export market has rapidly dwindled and by summer 2014, ceased to exist because of the US 'shale revolution' (Blas 2014), and as new 'exploration frontiers' (including pre-salt plays) are opening up elsewhere in the Gulf of Guinea and eastern Africa, it can no longer take for granted its competitiveness when it comes to attracting the best bids for its upstream operations that are necessary for sustaining a viable oil and gas economy. On the other hand, Nigeria's energy sector continues to attract investments from institutional investors and sovereign wealth funds in the Gulf and from the Asia Pacific region (Asu 2014), and from Chinese NOCs which remain willing to commit large-scale investments in onshore exploration where Western IOCs are increasingly concerned about operating (Daly 2014). Whatever the longer term rebalancing of Nigeria's energy industry may be, the substantial costs and risks associated with its energy industry will weigh heavily on its future development.

\subsection{South Africa}

Postcolonial politics matter in socio-economic contexts outside the typical petro-state as well. When, as in South Africa, the beneficiaries of resource revenues become 'colour coded' due to a colonial past involving racial domination (Chang et al. 2011), populist pressures for 
nationalisation are likely to increase. Led by the ANC Youth League (ANCYL) and its former firebrand leader, Julius Malema, radical/left-wing factions of South Africa's governing alliance (comprised of the ANC, the South African Communist Party (SACP) and the Congress of South African Trade Unions (COSATU)), managed in recent years to reintroduce the question of nationalisation of the country's vast mineral assets onto the national agenda. Malema's call for nationalisation without compensation was a 'central aspect' of his successful re-election in 2011 as leader of the ANCYL, and the intense societal debate provoked by his stance made the National Union of Mineworkers revise its previous opposition to nationalisation (Leon 2012, p. 21). More moderate actors have also raised the prospect of nationalisation. In the wake of increasing labour militancy, violent confrontations between miners and police, and the prospect of major reductions in work forces and reduced investments by mining operators, COSATU's Spokesperson, Patrick Craven, argues that 'we have a point about nationalization', and that the main role of COSATU 'will be to keep [the] debate about nationalization alive and make sure it's never off the table' (Maylie 2013).

This tension regarding control of the country's mineral resources persists despite the fact that the ANC elites, many of them also members of the SACP, had made it quite clear during the early 1990s transition to democracy that they had no plans for large-scale nationalisation (Butler 2013). The Cold War (rhetorical) threat of nationalisation, originating in the anti-apartheid struggle's 1955 Freedom Charter which proclaimed that '[t]he mineral wealth beneath the soil ... shall be transferred to the ownership of the people as a whole', was generally discounted by South Africa's powerful mining houses once the ANC came to power in 1994, even if the financial press raised concerns about such threats and their impact on foreign investment (Davis 2001, p. 135). In the end, economic rationale trumped populist and anti-colonial rhetoric at the ANC's 2012 party conference in Mangaung where the government decidedly eschewed outright nationalisation (Butler 2013).

The influence within the ANC leadership of a 'rational centre' concerned with the economic costs of nationalisation has, according to Butler (2013), been a key reason why the ANC government has so far thwarted popular pressures for a more radical approach to redressing the ownership patterns which, despite more than a decade of BEE policies, are still evoking the country's apartheid past:

Former presidency policy head and planning commission member Joel Netshitenzhe has remained an influential voice for the rational centre of the ANC. He has observed 
that the key obstacles to investment in South Africa's minerals sector in recent years have been 'infrastructure bottlenecks, long lead-times in acquiring machinery, the volatility of the exchange rate, insufficient capacity within the then [Department of Minerals an Energy] in the early days of [the Minerals and Petroleum Resources Development Act] implementation and slow processing of environmental impact assessments ... The challenge, quite clearly, is not whether the mines are in state hands or not ... Even if the mines were owned by the state, without a sector plan, there would be no strategic logic to activities in the sector'. [Netshitenzhe, 2010 quoted in Butler 2013, p. 18]

Many uncertainties remain about the future of the minerals industry in South Africa (Leon 2012). The evolving nature of South Africa's mining legislation has long been a cause for concern in the industry and for investors. But critics point out that big mining companies, such as De Beers, pay much lower royalty rates on their profits in South Africa than miners elsewhere in Africa, with royalties not being paid at all until 2010. De Beers also did not pay any export taxes on diamonds until 2007. Until 2010, South Africa was the only mining country in sub-Saharan Africa where no royalties were paid. And, whereas mining royalties in neighbouring Botswana and Namibia are fixed at 10\%, South Africa applies a sliding scale ranging from $0.5 \%$ to $7 \%$, with the average rate paid being only $2 \%$. In 2011 , South Africa produced $12 \%$ of all rough diamonds in the world, yielding a meagre US\$11 million in mining royalties (Sharife 2014). Thus, critics of this regime argue that South Africa is failing to benefit properly from its natural resources.

But the mining companies would argue that poor labour relations are to blame. The recently concluded strike in the platinum sector has, since the beginning of 2014, cost them some US\$2 billion in lost revenue and a 25\% drop in mining output. Labour unrest on the mines resulted in 70,000 miners being out of work for several months and has contributed to economic contraction. As a consequence, the ratings agency S\&P downgraded South Africa's credit rating to $\mathrm{BBB}$ - just one notch above 'junk' status (England 2014b). On the legislation front, it is a recently approved Minerals and Petroleum Resources Development Act (MRPDA) Amendment Bill that is at the centre of industry concern. In particular, the bill will have a significant impact on the government's participation in mining licenses. Earlier versions of this bill would have introduced a $20 \%$ free carry interest for the state in new mining projects with, importantly, the state's total interest not being able to exceed $50 \%$. The 
approved bill, however, has removed the 50\% limit, 'effectively giving the State the right to take over an existing ... operation' (Kolver 2014). The government would also have to pay an 'agreed price' instead of a 'fair market value' for any participation in private sector operations. And, the government would give the Minister of Mineral Resources the power to declare certain minerals (such as iron ore, coal and platinum) as 'strategic' assets, meaning it would be able to enforce production volumes and prices of these minerals in the domestic market. The fact that the bill also removes certain safeguards requiring mining companies to address 'social and economic needs' of local communities, might also fuel conflict over ownership if communities feel even more excluded from the profits made by the industry than they already are (Kolver 2014). South African politics remain affected by the legacy of apartheid and it is in that context that the future of the country's resources industry must be considered. This is a future that clearly does not preclude various forms of resource nationalism.

\subsection{Mozambique}

Mozambique offers a different perspective on resource nationalism in sub-Saharan Africa to that of mature oil and minerals markets in Nigeria and South Africa. Whereas the potential for Mozambique to exploit gas had already been identified in the 1960s, the armed struggle for independence in the 1970s and the 1980s civil war prevented further exploration of the country's resources. By 2003, however, the South African energy company SASOL began to develop natural gas in the south of the country, allowing Mozambique to export the gas to South Africa by 2004. The country is now on the cusp of becoming one of the region's major energy exporters (Gqada 2013). The discovery of massive natural gas deposits off-shore in the Rovuma Basin in the north of the country in the border region with Tanzania has triggered plans for major investments in LNG export facilities (Melina and Xiong 2013, pp. 4-5). However, 'the journey ... to sustainable economic development is long and arduous', and foremost among the country's challenges with important implications for the future of its energy industry 'is the need to tackle a pernicious culture of corruption' (Levy and Williams 2014, p. 236).

The natural gas discoveries in Mozambique are impressive. Its estimated reserves in 2013 of 200 tcf would, if proven, result in Mozambique possessing the eighth largest reserves in the world (Melina and Xiong 2013, p. 5). The country could, according to PWC (2013), become the world's fourth largest exporter of LNG and the second largest in Africa after 
Nigeria, by 2025. The US gas exploration company Anadarko has discovered some 50-70 tcf of natural gas in one of its offshore fields. It could, according to Anadarko Executive Chairman Jim Hackett (quoted in SPTEC Advisory 2013), become 'one of the most important natural gas fields discovered in the last ten years, with significant long-term benefits for Mozambique'. Italy's Eni, as well as Norway's Statoil and Malaysia's Petronas, among others, are also exploring the region's newfound gas riches. Given that this transformation is taking place in what remains, despite impressive growth rates in recent years, one of the world's poorest countries where, according to the World Bank, a mere $20 \%$ of the population has access to electricity, it is bound to become increasingly contested by both elites and wider society. Indeed, given how little the people of Mozambique have benefited from the country's national resource industry so far, there will be significant pressure on the government to avoid the pitfalls associated with rapid increases in energy revenues that have befallen so many other African countries (Gqada 2013).

Unlike in Nigeria, however, the energy industry in Mozambique is in its early stages and the political climate is different from that of the 1970s: there is no realistic option to take control of the country's energy industry by means of expropriation. Unlike in South Africa, too, there is no similarly symbolic attachment to a resources industry in which generations of labour leaders have gained their formative experiences. Thus we would expect a rather different debate in Mozambique about the exploitation of the country's newfound resource wealth. Mozambique is clearly more dependent on the expertise and the investments by IOCs and NOCs than are Nigeria and South Africa. This is, in part, because costs are not yet sunk in Mozambique's energy fields to the extent that they have been over decades in Nigeria's energy industry and for over a century in South Africa's mining industry. That said, Mozambique's government is considering all options in terms of how its future ownership and involvement in the gas industry will best enable it to achieve its political, economic and developmental aims. The national oil company, Empresa Nacional de Hidrocarbonetos, is already in possession of a $15 \%$ stake in 'key projects' and is exploring how to increase this stake in new gas projects coming on stream. Given the limited finances of the company, such plans could be facilitated by various taxes on mergers and acquisitions in the industry (Maylie 2014). Until recently, however, Gqada (2013, p. 15) argues that 'large foreign companies will enjoy a relatively favourable fiscal and tax regime designed to attract even greater inward financial flows' and that this is necessary for Mozambique 'to achieve greater benefit from economic activities within its borders, particularly those in the extractive sector'. 
The extractive industries have played an important role in Nigeria and South Africa, and are beginning to do so in Mozambique. These examples suggest a continued relevance of, or potential for, resource nationalisation as an instrument in the social and political contestation over natural resource assets. But patterns of resource nationalism will not simply be replicated across countries. It is therefore useful to consider how the evolution of resource nationalism in sub-Saharan Africa might map onto ideal types of resource nationalism, thus linking them to similar dynamics worldwide.

\section{Varieties of resource nationalism}

Bremmer and Johnston (2009, pp. 150-2) outline four variants of resource nationalism, each of which differs in terms of motivating factors and also in terms of their impact on resource industries and on investment patterns in these industries. Firstly, they identify Russia and Venezuela as examples of 'revolutionary resource nationalism'. This type is distinct in that it does not simply aim to increase state control over resources (in the energy and minerals sectors), but is also linked to 'broader political and social upheaval'. Putin's consolidation of power in Russia and attempts to reassert Russia's regional power in Eastern Europe, as well as Chavéz's 'Bolivarian revolution', fit this pattern. This type of resource nationalism can have severe effects on IOCs, such as the operations of Shell in Russia and ExxonMobil in Venezuela:

Ownership of prized assets may be wrenched away through forced renegotiation of existing contracts, using perceived historical injustice or alleged environmental or contractual misdeeds by the companies as justification. These actions tend to be topdown, arbitrary and accompanied by little if any compensation or recourse. [Bremmer and Johnston 2009, p. 150]

It is difficult to place any of the significant energy or mineral exporters in subSaharan Africa today into this variant of resource nationalism. Arguably, Zimbabwe's economic policy of 'indigenisation', which aims to ensure African majority control of economic sectors in the country, including its tentatively recovering mining industry (Magure 2012), comes closest to resembling this type. These indigenisation policies are linked to broader societal aims, most importantly the shoring up of power by the ZANU-PF Government by means of brandishing its liberation and anti-colonial credentials (Andreasson 
2010; Ndlovu-Gatsheni 2009). On the other hand, Zimbabwe's ambitions are not nearly as significant regionally as are those of Russia and Venezuela. There are wider repercussions, as Zimbabwean President Robert Mugabe's rhetoric about the need to nationalise land and other resources in order to complete the liberation from colonial oppression has resonated with leaders and publics in South Africa and Namibia and thus shaped public debate in those countries (cf. Southall 2014). But by comparison to the regional repercussions of Putin's and Chavéz's politics, those of Mugabe are rather modest even if the domestic consequences for Zimbabwe might initially have been more ruinous.

Secondly, 'economic resource nationalism' is a more common form of resource nationalism. By contrast to the 'revolutionary' type, economic nationalism tends to emerge in stable political environments, and is not dependent on political transitions or other societal upheaval. Johnston and Bremmer (2009, p. 151) use Kazakhstan as an example. Here, a 'rebalancing' of assets in the country's oil industry, from private to state control, was the key change that took place. In this type of resource nationalism, it is less the actual ownership, and even political control, of resources that is at stake. Rather, it aims primarily to increase the fiscal revenues gained by the state from its resources. This is an incremental type of resource nationalism that can be observed in, for instance, South Africa's mature mining industry, as well as in other sectors, where the ANC Government has, in recent years, attempted to increase black inclusion and ownership by means of BEE legislation (Hamann et al. 2008). In the mining industry, these efforts also include more forcefully exercising the state's control over mining licenses and the benefaction of mining profits. We might also see this kind of 'economic nationalism' in the frontier markets that are recently being discovered, such as the natural gas industries of Mozambique and Tanzania, where the state is looking to new legislation as a means to increase its share of energy resource revenues (Maylie 2014).

'Legacy resource nationalism' is a third variant that is characterised by a longestablished history of nationalisation of natural resource assets and where that nationalisation 'is central to national political and cultural identity' (Bremmer and Johnston 2009, p. 151). They consider it 'the most ingrained variant, with the most durable impact on industry and oil prices'. Mexico is an obvious example with its early nationalisation in 1938 that has since played a hugely symbolic role in that country. The recent decision by the government of Enrique Pena Nieto to open up the country for foreign oil and gas exploration for the first time since 1938 was very controversial and required three amendments to Mexico's constitution before being signed into law in 2013 (BBC News 2013). Nigeria is a clear case of 
this kind of 'legacy' resource nationalism in sub-Saharan Africa. It was established relatively early on in the post-independence era and has since become central to Nigeria's economic and political trajectories, as well as to its identity as sub-Saharan Africa's leading petro-state, which gives the country some significant political influence. The 'oil power' generated by nationalisation in the 1970s made it possible for Nigeria to play an important role in West African integration and also in providing support to liberation movements in Southern Africa (Soremekun 2011, p. 99). That the culmination of the process whereby Nigeria re-asserted state control over its oil riches came in the form of nationalising the assets of British Petroleum, a business icon of Nigeria's former colonial rulers, only serves to cement the sense of legacy. Much of the bitterness in relations between Shell, which retained a major role in Nigeria's energy industry, and Nigerian society, stems from this neo-colonial history of relations between Britain and Nigeria (cf. Umejesi and Akpan 2013).

Finally, Bremmer and Johnston (2009, p. 152) identify a 'soft resource nationalism' that is often found in OECD countries, as opposed to the developing countries where we normally expect resource nationalism to be a particularly prominent phenomenon. This kind of nationalism is, according to the authors, 'rampant' in countries such as Canada and the UK, and is also increasingly present in the USA and Australia. While the motivations for governments in these countries may be similar to those in (developing) countries exercising other forms of resource nationalism - aims often include increasing state control of resource industries, enhancing state revenues from production and persuading resource companies to improve their record in terms of environmental standards and corporate social responsibility they differ in that they tend not to terminate existing contracts and engage in 'arbitrary action' to achieve these goals. The developed countries taking this 'soft' approach to resource nationalism tend rather to increase royalties on resource profits and change tax regimes 'through established regulatory or legislative channels' in order to achieve desired outcomes. The absence of state-owned energy companies in most of these countries is also an explanation for the choice of this 'soft' approach to resource nationalism rather than more arbitrary measures. However, the blocking by the US Congress in 2005 of the China National Offshore Oil Corporation's (CNOOC) attempt to purchase US oil company Unocal on grounds of 'national security' suggests that not-so-soft forms of resource nationalism may be employed in OECD countries as well (Kim 2007, pp. 168-9).

South Africa may, from a critical perspective, most clearly resemble a case of 'economic resource nationalism'. This assuming that the newly formed Economic Freedom 
Fighters (EFF) party, headed by the ousted ANCYL leader Julius Malema and which gained over $6 \%$ of the vote in the country's 2014 national elections, and others who would like to see the expropriation of the country's mining industry, do not come to power (Bond 2014). A more generous analysis may however suggest that South Africa's policies are perhaps the best example in sub-Saharan Africa of the 'soft' type of resource nationalism. After all, the safeguards for private property that were established in the post-apartheid constitution have been upheld, and in that sense it could be said that South Africa promotes change with respect to ownership and control of its mining industry through the same regulatory and legislative channels as do the OECD countries. Of course, the historical legacy of South Africa, and therefore the presence of a volatile societal and political contention over the ownership of these resources, produces a different debate about natural resource industries than is the case in developed countries (cf. Leon 2012).

\section{Conclusion}

Resource nationalism will remain an option for governments in sub-Saharan Africa attempting to derive maximise profits and developmental benefits from their natural resources, whether as an actual policy instrument or merely a rhetorical means to steer political debate and amass public support. While the political economy literature tends to emphasise negative consequences of resource nationalism, outcomes have arguably been mixed and present both opportunities and risks for producer countries and resource companies alike. Where present, resource nationalism will also, per definition, constrain the operations of Western energy companies operating in the region. Moreover, the types of resource nationalism employed by countries in sub-Saharan Africa will continue to evolve and diversify, in that they represent a variety of resource nationalisms, such as those identified in Bremmer and Johnston's typology and are variously present in producer countries across the world.

This article has provided a broad examination of resource nationalism in sub-Saharan Africa's energy and minerals markets, focussing on Nigeria, South Africa and Mozambique. These three cases make clear that the different historical contexts and socio-political environments in which each country's resource industries emerge and develop will inevitably shape how they approach resource nationalism, as a potential tool for increasing their bargaining power vis-à-vis IOCs and NOCs alike and for attempting to promote development on the back of resource-led growth. This has clearly been difficult in the past, as attested to 
by the resource curse. Much is therefore at stake in terms of how developing countries in subSaharan Africa and beyond will manage these valuable resources. In terms of Bremmer and Johnston's (2009) four-fold typology of resource nationalisms, Nigeria approximates the 'legacy' type. From a critical perspective, South Africa constitutes an example of 'economic' resource nationalism. A more generous analysis would point to South Africa resembling 'soft' resource nationalism that is more common in developed countries. Because Mozambique is a newer entrant into the ranks of energy producers, it is more difficult to align with any of the four types of resource nationalism, although it is likely another example of the 'economic' type. None of these countries fit clearly into the 'revolutionary' type of resource nationalism.

In the end, however, Bremmer and Johnston (2009) are rather sceptical about the future of resource nationalism. They argue that more robust approaches to increasing state ownership and control over natural resources are less likely to yield the benefits that these states assume they will and are often in fact rather costly to their economic development. They also point out that most resource nationalism today is of the economic rather than the revolutionary type, meaning that its long-term effects may be less severe than is commonly assumed and leading more often to international resource companies reconsidering new projects rather than being forced to terminate or hand over existing ones (Bremmer and Johnston 2009, p. 155). This, then, is a rather benign and perhaps predictable conclusion, suggesting merely that less contentious or 'softer' forms of resource nationalism will become the 'new normal' according to which IOCs and others will have to conform. It is worth noting, though, that with constant pressures on IOCs to replace their rapidly depleting reserves so as to remain viable (Coll 2012), even having to reconsider and perhaps refrain from participating in new developments might have significant consequences for their bottom line and thus for a range of geostrategic and economic aspects of global energy markets. Shell's and BP's recent difficulties with heavily invested projects in Russia due to Western sanctions against Putin's government following the annexation of Crimea and subsequent war in Eastern Ukraine is a case in point.

Looking ahead, these findings suggest additional venues for research that would further unpack the notion of varieties of resource nationalism - where different types are likely to emerge and what the consequences would be. Is there a difference in approaches to resource nationalism by governments in markets where energy and minerals extraction has a long and significant history, and/or where methods of extraction and exploitation are 
relatively less technologically complex (and therefore often also less financially demanding), as compared to those markets where resource industries are developed more recently and/or the processes more complex? Possibly it is the case that the propensity towards resource nationalism is higher in the former, where resource exploitation has a long history and is less complex and demanding. Moreover, comparing long-established mining markets such as those in Southern Africa with recently explored energy markets in central and Eastern Africa, in particular more complex operations in off-shore and deep water blocks, could identify potential differences in tendencies towards resource nationalism in mining versus energy markets and in markets where on-shore rather than off-shore dominates. The impact of regime type (i.e., the propensity for nationalism in democracies such as South Africa versus in authoritarian regimes such as Zimbabwe) is also worthy of further exploration. These earthly riches will last for a long time yet, and how best to exploit them will continue to be a most salient question for governments, resource companies and civil societies alike. 


\section{References}

Adam, H., Van Zyl Slabbert, F. and Moodley, K. 1998. Comrades in Business: PostLiberation Politics in South Africa. International Books, Utrecht.

African Development Bank. 2010. Crude Oil and Natural Gas Production in Africa and the Global Market Situation. Commodities Brief 1. Retrieved 15.06.14 from http://www.afdb.org/fileadmin/uploads/afdb/Documents/Publications/Commodity $\% 2$ 0Brief\%200il\%20and\%20gas\%20Final.pdf.

African Development Bank. 2013. African Economic Outlook 2013, pocket ed. African Development Bank Group. Retrieved 17.06.14 from http://www.africaneconomicoutlook.org/fileadmin/uploads/aeo/PDF/Pocket\%20Editi on\%20AEO2013-EN.web.pdf.

Andreasson, S. 2005. Orientalism and African development studies: the 'reductive repetition' motif in theories of African underdevelopment. Third World Quarterly. 26, 971-986.

Andreasson, S. 2010. Confronting the Settler Legacy: Indigenisation and Transformation in South Africa and Zimbabwe. Political Geography. 29, 424-433.

Asu, F. 2014. Nigeria's oil industry attraction undermined by risks. Business Day. Retrieved 17.06.14 from http://businessdayonline.com/2014/06/nigerias-oil-industry-attractionundermined-by-risks/.

Azapagic, A. 2004. Developing a framework for sustainable development indicators for the mining and minerals industry. Journal of Cleaner Production. 12, 639-662.

Barry, J. 2012. The Politics of Actually Existing Unsustainability: Human Flourishing in a Climate-Changed, Carbon-Constrained World. Oxford University Press, Oxford.

BBC News. 2013. Mexican president signs controversial oil and gas law. 21 December. Retrieved 15.06.14 from http://www.bbc.co.uk/news/world-latin-america-25471212.

Blas, J. 2014. Victim of shale revolution, Nigeria stops exporting oil to US. Financial Times. Retrieved 30.12.14 from http://blogs.ft.com/beyond-brics/2014/10/02/victim-of-shalerevolution-nigeria-stops-exporting-oil-to-us/.

Bond, P. 2014. South Africa's Resource Curses and Growing Social Resistance. Monthly Review. 65. Retrieved 17.06.14 from http://monthlyreview.org/2014/04/01/southafricas-resource-curses-growing-social-resistance.

BP. 2013. Statistical Review of World Energy 2013. Retrieved 15.06.14 from http://www.bp.com/en/global/corporate/about-bp/energy-economics/statisticalreview-of-world-energy-2013.html. 
Bremmer, I. and Johnston, R. 2009. The Rise and Fall of Resource Nationalism. Survival. 51, 149-158.

Butler, A. 2013. Resource Nationalism and the African National Congress. The Journal of The Southern African Institute of Mining and Metallurgy. 113, 11-20.

Candy, G. 2013. Africa could still benefit from resources boom. Mineweb. Retrieved 17.06.14 from http://www.mineweb.com/mineweb/content/en/mineweb-politicaleconomy?oid=191746\&sn=Detail.

Chang, R., Hevia, C. and Loayza, N. 2010. Privatisation and Nationalisation Cycles. NBER Working Paper No. 16126. Retrieved 12.06.14 from http://www.nber.org/papers/w16126.

Chua, A. L. 1995. The Privatisation-nationalisation cycle: The link between markets and ethnicity in developing countries. Columbia Law Review. 95, 223-303.

Coll, S. 2012. Private Empire: ExxonMobil and American Power. Penguin Books, London.

Collier, P. 2010. The Plundered Planet: Why We Must - and How We Can - Manage Nature for Global Prosperity. Oxford University Press, Oxford.

Daly, J. 2014. China's Bold \$10 Billion Investment in Nigerian Hydrocarbons. OilPrice.com. Retrieved 17.06.14 from http://oilprice.com/Energy/Crude-Oil/Chinas-Bold-10Billion-Investment-in-Nigerian-Hydrocarbons.html.

Davis, G. A. 2001. The Credibility of a Threat to Nationalize. Journal of Environmental Economics and Management. 42, 119-139.

De Graaff, N. 2011. A global energy network? The expansion and integration of non-triad national oil companies. Global Networks. 11, 262-283.

Doner, R. F. 1992. Limits of State Strength: Towards an Institutionalist View of Economic Development. World Politics. 44, 398-431.

Ecobank. 2013. IOC divestments in Nigeria: Opportunities, challenges and outlook. Retrieved 14.06.14 from http://www.ecobank.com/upload/20130830040551692479EzAyDnvCXt.pdf.

England, A. 2014a. Gill Marcus: telling it straight as S Africa faces threat of downgrade. Financial Times. Retrieved 12.06.14 from http://blogs.ft.com/beyondbrics/2014/06/10/gill-marcus-telling-it-straight-as-s-africa-faces-downgrade/.

England, A. 2014b. S\&P downgrades South Africa as mining strike takes toll. Financial Times. Retrieved 17.06.14 from http://www.ft.com/cms/s/0/14c7a586-f2cf-11e3a3f8-00144feabdc0.html. 
Financial Times. 2014. Finding Nigeria's missing billions: Shooting the messenger does not nullify the message. Retrieved 13.06.14 from http://www.ft.com/cms/s/0/1a1b4252a853-11e3-8ce1-00144feab7de.html.

Frynas, J. G. 2000. Oil in Nigeria: Conflict and Litigation between Oil Companies and Village Communities. LIT Verlag, Münster.

Frynas, J. G., Beck, M. P., and Mellahi, K. 2000. Maintaining Corporate Dominance after Decolonization: the "First Mover Advantage" of Shell-BP in Nigeria. Review of African Political Economy. 27, 407-425.

Genova, A. 2010. Nigeria's Nationalization of British Petroleum. International Journal of African historical Studies. 43, 115-136.

Gqada, I. 2013. A Boom for Whom? Mozambique's Natural Gas and the New Development Opportunity. Occasional Paper No 151. South African Institute of International Affairs. Retrieved 17.06.14 from http://www.saiia.org.za/doc download/349-a-boomfor-whom-mozambique-s-natural-gas-and-the-new-development-opportunity.

Guriev, S., Kolotilin, A., and Sonin, K. 2011. Determinants of Nationalization in the Oil Sector: A Theory and Evidence from Panel Data. The Journal of Law, Economics, \& Organization. 27, 301-323.

Hamann, R., Khagram, S., and Rohan, S. 2008. South Africa's Charter Approach to PostApartheid Economic Transformation: Collaborative Governance or Hardball Bargaining? Journal of Southern African Studies. 34, 21-37.

Hancock, K. J. and Vivoda, V. 2014. International political economy: A field born of the OPEC crisis returns to its energy roots. Energy \& Social Science Research. 1, 206216.

Hillbom, E. 2012. Botswana: A development-oriented gate-keeping state. African Affairs. 111, 67-89.

ICMM. 2012. The role of mining in national economies: Mining's contribution to sustainable development. Retrieved 15.06.14 from http://www.icmm.com/document/4440.

IEA. 2014. Africa Energy Outlook: A Focus on Energy Prospects in Sub-Saharan Africa. Executive Summary. International Energy Agency, Paris.

Iheduru, O. C. 2002. Social Concertation, Labour Unions and the Creation of a Black Bourgeoisie in South Africa. Commonwealth \& Comparative Politics. 40, 47-85. Ikelegbe, A. 2005. The Economy of Conflict In the Oil Rich Niger Delta Region of Nigeria. Nordic Journal of African Studies. 14, 208-234. 
IMF. 2012. Regional Economic Outlook - Sub-Saharan Africa: Maintaining Growth in an Uncertain World. International Monetary Fund, Washington, DC. Retrieved 12.06.14 from http://www.imf.org/external/pubs/ft/reo/2012/afr/eng/sreo1012.pdf.

Jackson, R. H. and Rosberg, C. G. 1982. Why Africa's Weak States Persist: The Empirical and the Juridical in Statehood. World Politics. 35, 1-24.

Jensen, N. M. and Johnston, N. P. 2011. Political Risk, Reputation, and the Resource Curse. Comparative Political Studies. 44, 662-688.

Jensen, N. and Wantchekon, L. 2004. Resource Wealth and Political Regimes in Africa. Comparative Political Studies. 37, 816-841.

Joffé, G., Stevens, P., George, T., Lux, J. and Searle, C. 2009. Expropriation of oil and gas investments: Historical, legal and economic perspectives in a new age of resource nationalism. Journal of World Energy Law \& Business. 2, 3-23.

Karl, T. L. 1997. The Paradox of Plenty: Oil Booms and Petro-States. University of California Press, Berkeley.

Kim, J. 2007. Fears of Foreign Ownership: The Old Face of Economic Nationalism. SAIS Review of International Affairs. 27, 167-177.

Kolver, L. 2014. Corrupt Africa failing to benefit from resources boom, says Peter Leon. Mining Weekly. Retrieved 17.06.14 from http://www.miningweekly.com/printversion/corrupt-africa-failing-to-benefit-from-resources-boom-says-peter-leon-200712-14.

KPMG Africa. 2013. Oil and Gas in Africa: Africa's Reserves, Potential and Prospects. Retrieved 12.06.14 from http://www.kpmg.com/Africa/en/IssuesAndInsights/ArticlesPublications/Documents/Oil\%20and\%20Gas\%20in\%20Africa.pdf.

Lagarde, C. 2014. Africa Rising - Building to the Future'. Keynote Address. Maputo. Retrieved 13.06.14 from http://www.imf.org/external/np/speeches/2014/052914.htm.

Le Billon, P. 2001. The political ecology of war: natural resources and armed conflicts. Political Geography. 20, 561-584.

Leon, P. 2012. Whither the South African Mining Industry? Journal of Energy \& Natural Resources Law. 30, 5-28.

Levy, S. and Williams, C. 2014. Mozambique's pathway to probity: evolving legal responses to corruption. Journal of World Energy Law \& Business. 7, 236-254.

Lipton, M. 1986. Capitalism and Apartheid: South Africa 1910-1986. Wildwood House, Aldershot. 
Magure, B. 2012. Foreign investment, black economic empowerment and militarised patronage politics in Zimbabwe. Journal of Contemporary African Studies. 30, 67-82. Maylie, D. 2013. Mining Debate Rattles South Africa. The Wall Street Journal. Retrieved 28.12.14 from http://www.wsj.com/articles/SB10001424127887323309604578430833278491840. Maylie, D. 2014. African Nations Seek Sway Over Oil, Gas Development. The Wall Street Journal. Retrieved 14.06.14 from http://online.wsj.com/news/articles/SB10001424052702304483804579284713169127 356.

McKinsey \& Company. 2010. Africa's path to growth: Sector by sector. Retrieved 12.06.14 from http://www.mckinsey.com/insights/economic_studies/africas_path_to_growth_sector_ by sector.

Melina, G. and Xiong, Y. 2013. Natural Gas, Public Investment and Debt Sustainability in Mozambique. IMF Working Paper, WP/13/261. Retrieved 14.06.14 from http://www.imf.org/external/pubs/ft/wp/2013/wp13261.pdf.

Moran, T. H. 1973. Transnational Strategies of Protection and Defense by Multinational Corporations: Spreading the Risk and Raising the Cost for Nationalization in Natural Resources. International Organization. 27, 273-287.

Myburgh, J. 2012. Natural gas discoveries put East Africa on world energy map. MNN.com. Retrieved 13.06.14 from http://www.mnn.com/earth-matters/energy/stories/naturalgas-discoveries-put-east-africa-on-world-energy-map.

Netshitenzhe, J. 2010. State ownership and the NDR: Debating nationalisation. Umrabulo. 33. Retrieved 14.06.14 from http://www.anc.org.za/show.php?id=2832.

Ndlovu-Gatsheni, S. 2009. Making Sense of Mugabeism in Local and Global Politics: "So Blair, keep your England and let me keep my Zimbabwe”. Third World Quarterly. 30, 1139-1158.

OPEC. 2013. OPEC Annual Statistical Bulletin 2013. OPEC, Vienna. Retrieved 13.06.14 from

http://www.opec.org/opec_web/static_files_project/media/downloads/publications/AS B2013.pdf.

Ovadia, J. S. Forthcoming. The Petro-Developmental State in Africa: Making Oil Work in Angola, Nigeria and the Gulf of Guinea. Hurst \& Co, London. 
PWC. 2013. From promise to performance: Africa oil \& gas review. Retrieved 14.06.14 from http://www.pwc.co.za/en_ZA/za/assets/pdf/africa-oil-and-gas-review-2013.pdf.

Rist, G. 2002. The History of Development: from Western Origins to Global Faith. Zed Books, London.

Ross, M. L. 1999. The Political Economy of the Resource Curse. World Politics. 51, 297 322.

Ross, M. L. 2006. A Closer Look at Oil, Diamonds, and Civil War. Annual Review of Political Science. 9, 265-300.

Ross, M. L. 2012. The Oil Curse: How Petroleum Wealth Shapes the Development of Nations. Princeton University Press, Princeton.

Sala-i-Martin, X and Subramanian, A. 2003. Addressing the Natural Resource Curse: An Illustration from Nigeria. NBER Working Paper No. 9804. Retrieved 13.06.14 from http://www.nber.org/papers/w9804.

Sharife, K. 2014. Rough and polished: South Africa short-changed on diamond trade. Pambazuka. 682. Retrieved 16.06.14 from http://www.pambazuka.org/en/category/features/92091.

Shaxson, N. 2007. Poisoned Wells: The Dirty Politics of African Oil. Palgrave Macmillan, New York.

Soares de Oliveira, R. 2007. Oil and Politics in the Gulf of Guinea. Hurst and Company, London.

Soremekun, K. 2011. Nigeria's oil diplomacy and the management of the Niger Delta Crisis, in: Obi, C and Rustad, A. (Eds.), Oil and Insurgency in the Niger Delta: Managing the Complex Politics of Petro-Violence. Zed Books, London, pp. 99-111.

Southall, R. 2008. The ANC for Sale? Money, Morality \& Business in South Africa. Review of African Political Economy. 35, 281-299.

Southall, R. 2014. Threats to Constitutionalism by Liberation Movements in Southern Africa. Africa Spectrum. 49, 79-99.

SPTEC Advisory. 2013. Mozambique - The Emergence of a Giant in Natural Gas. 2012 Country Review. Retrieved 14.06.14 from http://www.sptecadvisory.com/SPTEC_Advisory-MozambiqueThe_Emergence_of_a_giant_in_Natural_Gas.pdf. 
Stevens, P. 2008. National oil companies and international oil companies in the Middle East: Under the shadow of government and the resource nationalism cycle. Journal of World Energy Law \& Business. 1, 5-30.

Umejesi, I. and Akpan, W. 2013. Oil Exploration and Local Opposition in Colonial Nigeria: Understanding the Roots of Contemporary State-Community Conflict in the Niger Delta. South African Review of Sociology. 44, 111-130.

UN. 2010. Aid to Africa. Policy Brief No. 1. United Nations Office of the Special Advisor on Africa. Retrieved 13.06.14 from

http://www.un.org/africa/osaa/reports/2010_Aidbrief.pdf.

Victor, D. G., Hults, D. R. and Thurber, M. (Eds.). 2012. Oil and Governance: State-Owned Enterprises and the World Energy Supply. Cambridge University Press, Cambridge. Vivoda, V. 2009. Resource Nationalism, Bargaining and International Oil Companies: Challenges and Change in the New Millennium. New Political Economy. 14, $517-$ 534.

Watts, M. 2004. Resource curse? Governmentality, oil and power in the Niger Delta, Nigeria. Geopolitics. 9, 50-80. 